\title{
External Radiotherapy of Thyroid Cancer
}

\author{
B. Pöllinger E. Dühmke \\ Klinik und Poliklinik für Strahlentherapie und Radioonkologie der Ludwigs-Maximilians-Universität München
}

\author{
Key Words \\ Thyroid cancer · Radioiodine therapy · External beam \\ radiotherapy
}

\section{Summary}

Differentiated thyroid cancer comprises papillary, mixed papillary-follicular and follicular adenocarcinomas. They are mostly hormone-sensitive and respond to thyroidstimulating hormone (TSH) suppression. The standard treatment is total thyroidectomy. ${ }^{131}$ I therapy and thyroid hormone suppression therapy. Adjuvant external radiotherapy is discussed controversially. Most authors recommend adjuvant external radiotherapy for extracapsular tumor extension. Decision on an individual basis should be made for patients with lymph node involvement. In the case of incomplete surgical resection, external radiotherapy should be applied if second surgery is not possible. For medullary thyroid cancer, external beam radiotherapy seems to be beneficial for patients with surgically inaccessible disease, with microscopic residual or gross tumor after surgery, with recurrent locoregional disease, or with surgically unmanageable metastases. Patients suffering from anaplastic thyroid cancer should receive combined treatment consisting of extensive surgery, external irradiation with total doses up to $60 \mathrm{~Gy}$, and chemotherapy. The combined treatment modality leads to higher local control rates and prolongs survival.

\section{Introduction}

The mainstay of treatment for differentiated thyroid cancer is surgery, consisting for the majority of patients in a total thyroidectomy, followed by ${ }^{131}$ I ablation of the residual thyroid tissue and thyroid hormone suppression therapy. In the case of incomplete surgical resection, if a second surgery is not possible and in patients with extra-capsular tumor extension, additional external beam radiotherapy is useful to achieve local control. H owever, the indication for external beam radiotherapy
Schlüsselwörter

Schilddrüsenkarzinom · Radiojodtherapie - Externe Strahlentherapie

\section{Zusammenfassung}

Differenzierte Schilddrüsenkarzinome werden in papilläre, gemischt papillär-follikuläre und follikuläre Adenokarzinome unterteilt. Sie sind meist hormonabhängig und ihr Wachstum kann durch Thyrotropin (TSH)-Suppression gehemmt werden. Die Standardtherapie umfaßt totale Thyroidektomie, postoperative Radiojodtherapie und Hormontherapie. Die Rolle der adjuvanten externen Strahlentherapie wird kontrovers diskutiert. Von den meisten Autoren wird die Indikation zur externen Strahlentherapie bei kapselüberschreitendemTumorwachstum gestellt. Die Indikation bei Lymphknotenbefall sollte individuell gestellt werden. Bei positiven Resektionsrändern sollte, falls ein erneutes chirurgisches Vorgehen nicht möglich ist, die externe Strahlentherapie durchgeführt werden. Bei medullären Schilddrüsenkarzinomen ist die externe Strahlentherapie bei Inoperabilität, bei postoperativ mikroskopischem oder makroskopischem Tumorrest, beim loko-regionalen Rezidiv und bei inoperablen Metastasen indidziert. Bei Patienten mit anaplastischem Schilddrüsenkarzinom verspricht eine kombinierte Therapie, bestehend aus möglichst weitgehender Tumorentfernung, externer Strahlentherapie mit Gesamtdosen um 60 Gy und Chemotherapie, die beste lokale Kontrolle und das längste Überleben.

is discussed controversially. In this article we summarize the present treatment options and discuss the situation where external radiotherapy might be beneficial.

\section{Differentiated Thyroid Cancer}

Differentiated thyroid cancer compries of papillary, mixed papillary-follicular, and follicular adenocarcinoma.

\section{KARGER}

Fax +497614520714

E-mail Information@K arger.de

www.karger.com c) 2001 S. Karger G mbH , Freiburg

A ccessible online at:

www.karger.com/journals/onk
Dr. Barbara Pöllinger

K linik für Strahlentherapie und R adioonkologie der

Ludwigs-M aximilians-U niversität

K linikum Innenstadt

Ziemssenstraße 1, D-80336 M ünchen (G ermany)

Tel. +49 89 5160-7560/7565, Fax - 7562 
Papillary thyroid cancer is slow-growing and often multicentric. It is diagnosed mostly at age $30-50$. The prognosis is excellent. This tumor usually grows infiltrative and metastasizes to regional lymph nodes through lymphatic channels. $\mathrm{H}$ ematogenous metastases are uncommon.

Follicular carcinomas are unifocal, have a marked tendency to invade vascular channels, and metastasize hematogenously to distant sites. Lymph node metastases are uncommon. The average age at diagnosis is $50-60$ years.

The 10-year survival rate of papillary thyroid cancer with $78-91 \%$ is better than of follicular thyroid cancer with $66-78 \%$ [1-3].The more unfavorable outcome of the follicular thyroid carcinoma may depend on the more common distant metastases and the often higher age at diagnosis.

The mainstay of treatment for differentiated thyroid cancer is surgery, consisting of a total thyroidectomy and regional lymphadenectomy, followed by ${ }^{131} \mid$ ablation of the residual thyroid tissue, and thyroid hormone suppression therapy. The indication for postoperative external radiation of differentiated thyroid cancer has remained an issue of controversial discussion, especially in the case of microscopic residual disease. It is generally restricted to those cases where local tumor control by postoperative ${ }^{131}$ I therapy alone seems doubtful $[4,5]$. Sautter-Bihl et al. [4] analyzed the problem of dose distribution of ${ }^{131}$ I $\beta$-radiation in a simulation model by $M$ onte Carlo techniques where tumors are tissue-equivalent spheres of various size.

H omogenous ${ }^{131}$ I distribution in the whole tumor volume as well as peripheral deposition confined to the tumor surface was analyzed. Extensive dose inhomogeneities appeared in small tumors. A s in local lymph node metastases tumoricidal radiation doses are not necessarily achievable by ${ }^{131}$ I therapy alone, postoperative external beam radiation should be considered in the clinical situation of lymph node involvement or occult micrometastases.

G ross Residual D isease and M icroscopic Residual Disease $O$ ne of the earliest reports on the use of external radiotherapy in thyroid cancer was by Sheline and co-workers [6]. In 1966 they reported on their experience with external radiotherapy in 58 patients treated between 1935 and 1964. They described the use of external beam radiotherapy in a variety of thyroid histologies and clinical situations. G iven the time period of the study, the techniques of radiation used would not be considered to be adequate today. The applied doses ranged from 30 to $50 \mathrm{G}$ y, given in $15-50$ days. Supplementary ${ }^{131}$ | therapy was not performed. 15 patients with papillary and 4 with follicular thyroid cancer had gross residual disease or inoperable recurrence in the surgical bed. For papillary tumors with follow-up ranging from 1 to 25 years, 8 patients were alive with no evidence of disease, and 4 showed local recurrences. $O f$ the 9 patients with palpable disease before external radiotherapy, 7 had a complete response and only 1 patient had a subsequent local relapse. The response in follicular tumors was similar.

These results suggest that external radiotherapy, even at suboptimal doses, may play a role in controlling gross disease in well-differentiated thyroid cancer and it may also contribute to local control in patients who following surgery, have microscopic residual disease in the neck. 0 'Connell et al. [7] described the Royal Marsden Hospital experience with 113 patients suffering from differentiated thyroid carcinoma. A II of them were treated with radical external radiotherapy (60 Gy in 30 fractions, over 6 weeks). A II received thyroid hormone suppression therapy with 74 undergoing additional ${ }^{131}$ I therapy. Three subgroups were defined according to residual disease status. In the probably microscopic residual disease group, 2 of 25 patients ( $8 \%$ ) developed an in-field recurrence. In the group of definite microscopic residual disease 5 of 18 (29\%) patients experienced in-field recurrences. Of the 32 patients with gross residual disease complete regression occurred in $37 \%$.

Tubiana et al. [8] reported a 40\% 15-year relapse-free survival rate and a 57\% 15-year survival rate in 97 patients with gross residual disease treated with external radiotherapy.

In a review of patients treated at Princess $M$ argaret $H$ ospital Tsang and co-workers [9] reported on 33 patients with gross residual disease, 20 were treated with external radiotherapy only and 13 had ${ }^{131}$ in addition to external beam radiotherapy. The 5-year local relapse-free rate was $62 \%$, and the causespecific survival rate was $65 \%$.

Phlips and co-workers [10] reported on 94 patients with differentiated thyroid cancer seen in their department from 1974 to 1989. 38 of these patients received a course of postoperative external irradiation. The indications for additional external irradiation were directly related to the quality of the surgical resection. A II patients had either macro- or microscopic residual disease or positive cervical lymph nodes with extracapsular extension. The results showed that additional external irradiation did not improve survival in this group. The 5 -year survival rates were $94 \%$ for the radioiodine group and $84 \%$ for the additional external radiation group. The local relapse rate was $21 \%$ for those who received radioiodine only, as compared to $3 \%$ for those who also received external beam radiotherapy. Potential bias could be introduced by the selection of the external radiation group, consisting of patients with worse prognosis. H owever, external radiation highly improved the locoregional control rate in these cases. External beam radiotherapy is a local therapy given with the intention to reduce the risk of local relapse. A s Phlips et al. stated, local control is certainly an important endpoint in thyroid cancer treatment because it avoids problems created by a relapse, such as recurrent nerve palsy, compression of the esophagus associated with dysphagia, and invasion of the trachea with hemoptysis. Furthermore, an increased risk for distant dissemination due to the persistence of neoplastic tissue is a potential problem.

\section{Extrathyroidal E xtension in D ifferentiated Thyroid Cancer}

The influence of external irradiation on survival rate in differentiated carcinomas exceeding organ boundaries was assessed in the evaluation of treatment results by L eisner and co-workers [1]. 167 patients with external irradiation (I) and 73 without external irradiation (II), but otherwise identical treatment, and differentiated carcinoma stage T 3 (stage T 4 when modern criteria are used) were compared. G roup I showed a 5- and 8-year survival of 88 and $75 \%$, group II of 68 and $38 \%$, respectively ( $p<0.001)$. L ocal recurrence occurred in $10 \%$ of both groups. $\mathrm{H}$ owever, metastases were found more frequently and earlier in group II (without external beam irradiation). This led the authors to recommend external radiotherapy in differentiated 
thyroid tumors with extracapsular extension. Therefore, external beam radiotherapy should be considered for patients with a risk for relapse of more than $10-20 \%$ in the thyroid bed. It is well recognized that extrathyroidal extension is a poor prognostic feature in differentiated thyroid cancer.

Samaann et al. [11] demonstrated on 1599 patients, treated at the M .D.A nderson Cancer Centre, that the risk for local recurrence increased with the extension of local tumor. If the tumor was confined to the thyroid gland, local recurrence rate was $19 \%$, with nodal involvement it increased to $22 \%$; but if there was infiltration of the soft tissues, it increased to $36 \%$. Survival at time of follow-up (median 11 years) was 93 and $94 \%$ for the first two groups, respectively, but decreased to $82 \%$ in patients with extrathyroidal extension and soft tissue involvement. $L$ ocal recurrence was the most common cause of death.

L erch and co-workers [12] found no significant influence of lymph node involvement on survival. In their group of 500 patients, higher mortality of patients with lymph node involvement was associated with high tumor stage (T4) and presence of distant metastases (M 1). They stated that lymph node involvement may influence recurrence. A djuvant external beam radiotherapy was not used in their study.

Tubiana et al. [8] reported on 66 patients who received adjuvant radiotherapy postoperatively for extensive regional lymph node involvement, tumor invasion of the neighboring muscles, or difficult surgical excision of recurrence after previous operation. The relapse-free survival and the overall survival rates for this group of patients given external beam radiotherapy with or without ${ }^{131}$ | was lower than for the group treated with surgery alone. However, external beam radiotherapy was performed on patients with less favorable prognosis. When the high-risk cases were pooled with the patients who had gross residual disease, the number of local recurrences was $14 \%$, as compared to $21 \%$ out of 336 patients who did not receive external beam radiotherapy $(p<0.05)$.

The importance of giving an adequate dose of external beam radiotherapy was demonstrated by a lower infield recurrence rate in patients who received doses greater than $50 \mathrm{G}$ y. These results suggest that adequate external beam radiotherapy improves local control in patients who are at risk of local relapse. Benker and co-workers [13] from E ssen/G ermany reviewed 932 patients. 346 had undergone external beam radiotherapy with a total dose from 40 to $70 \mathrm{G}$ y prior to ${ }^{131}$ I therapy. Survival was not prolonged following postoperative external beam radiotherapy. H owever, a subgroup analysis of patients older than 40 years with tumors $>4 \mathrm{~cm}$ or with tumors with extrathyroidal extension, revealed a 10 -year survival rate of $48 \%$ for those treated without external beam radiotherapy as compared to $58 \%$ for those who received external beam radiotherapy (this difference was not statistically significant). M ore recently, Farahati et al. [14], also from E ssen, reported on an increased freedom from locoregional and distant failure for patients over the age of 40 with extrathyroidal extension and lymph node involvement from papillary carcinoma who were treated with adjuvant external radiation therapy. It is important to note, that all patients had standard therapy of total thyroidectomy, 2 courses of ${ }^{131} \mathrm{I}$, and thyroid-stimulating hormone (TSH) suppression. The only treatment variable was the use of adjuvant external beam radiation therapy following the initial ${ }^{131}$ I therapy.
External beam radiation therapy was a predictive factor for improvement in time locoregional recurrence $(p=0.004)$ and locoregional and distant failure $(p=0.0003)$.

The participants of a G erman nuclear medicine meeting (1991, in H eidelberg) [15] advocated adjuvant external radiotherapy after surgery and ablative radioiodine therapy in patients suffering from a well-differentiated thyroid carcinoma with extrathyroidal extension. Surgery is performed with the intention of total thyroidectomy. O nly in very few cases macroscopic residual tumor is present after surgery. In this case, if second surgery is not possible, we would recommend to give ${ }^{131}$ | therapy followed by external beam radiotherapy and to continue with ${ }^{131}$ I therapy.

\section{Prognostic Factors}

Tennvall and co-workers [16] investigated other significant prognostic factors than those proposed by the EORTC Cooperative G roup. The E ORTC Co-operative Group identified prognostic significance for age, sex, cell type, clinical extent of tumor, lymph node involvement, and presence of distant metastases. A damietz and co-workers [2] identified the same factors during their rather long median follow-up of 11 years with advanced age being the most important prognostic factor

In the study of Leisner et al. [1], men died 1.5 times more frequently than women. The 10 -year survival rate was $90 \%$ in patients below the age of 50 years in contrast to $60 \%$ in older patients. Patients with papillary carcinoma showed a 10 -year survival rate of $78 \%$, whereas $66 \%$ of all patients with follicular carcinomas survived longer than 10 years.

Saur and co-workers [3] also revealed age, tumor invasion, and distant metastases as being of significant prognostic value. $\mathrm{No}$ correlation was demonstrated for sex and tumor histology. The authors recommend external beam radiotherapy in cases of incomplete tumor resection, in the presence of lymphangiosis carcinomatosa, and in anaplastic transformation.

Comparison of existing studies is difficult because of the diverse treatment modalities, e.g. extent of surgery, ${ }^{131}$ | therapy, irradiated volume, and applied doses. Further obstacles are introduced over the years by changes of the staging system.

The only way to define the role of external beam radiotherapy is to perform a prospective randomized trial of external beam radiotherapy against no external beam radiotherapy in patients considered to be at increased risk of relapse in the thyroid bed. Such a randomized trial has been opened for patient recruitment in December 1999 by the U niversity of M ünster/ Germany. R esults may be available in approximately 10 years.

\section{Conclusions}

In management of differentiated thyroid cancer, surgery and ${ }^{131}$ I therapy are standard treatment. The use of adjuvant external radiotherapy remains controversial. M ost authors recommend adjuvant external radiotherapy for extracapsular tumor extension. For patients with lymph node involvement the decision should be made with respect to the prognostic factors on an individual basis. I $n$ the case of incomplete surgical resection, external beam radiotherapy should be applied if re-operation is not possible.

In the thyroid bed doses of 60-66 Gy should be applied. The cervical lymph nodes up to the hyoid bone, the supra- and 
infraclavicular lymph nodes and the nodes in the ventral and upper mediastinum should receive doses of $50 \mathrm{G}$ y using single doses of 1.8-2.0 G y. The dose at the spinal cord should be limited to $40 \mathrm{G}$ y.

The potential benefit of external irradiation must be weighted against possible acute side effects (e.g. dry desquamation and rarely moist desquamation, mucositis, and weight loss) and late effects (fibrosis and nerve palsy). The acute side effects are reversible. D ue to their self-limiting nature a high frequency of dry desquamation and mucositis can be accepted. The late side effects are usually irreversible and therefore mostly considered as the dose-limiting end point. H owever, with the recommended doses the incidence of severe late effects is very low.

\section{Medullary Thyroid Cancer}

External irradiation for medullary thyroid cancer is discussed controversially in the literature. Prospective randomized trials have not yet been performed due to the rarity of the disease. A II reported series are retrospective by nature. $R$ ecent data indicate that external radiotherapy can be used for curative treatment in patients with microscopic residual or gross disease after surgery $[17,18]$. Tubiana et al. [8] reported similar survival rates for patients who received postoperative irradiation and for those who received surgery alone. Since the tumor was more limited in the patient group who received surgery alone, complete surgical excision was easier to achieve and involvement of the cervical lymph nodes was less frequent and less extensive [19].J ensen and colleagues [20] reported on 5287 cases of thyroid cancer. 191 patients (4\%) suffered from medullary cancer. $70 \%$ of these patients were treated with surgery alone. Surgery plus irradiation showed $100 \%$ survival at 5 years, compared with $91 \%$ survival after surgery alone.

In patients with microscopic residual disease the recommended dose is $60 \mathrm{~Gy}$ administered within 6-7 weeks. In cases with remnant gross disease or surgically unmanageable tumors, $65-70 \mathrm{G}$ y is advocated, with a reduced volume after $50-60 \mathrm{G}$ y. With bone metastases or inoperable mediastinal lymph node metastases, external irradiation is the most effective therapy and yields prolonged palliation in $75 \%$ of the patients.

\section{Conclusion}

External beam irradiation seems to be beneficial for patients with surgically inaccessible disease, for patients with microscopic residual or gross postoperative disease, for patients with recurrent locoregional disease, and in cases of metastases which are impossible to manage by surgery [21].

\section{Anaplastic Thyroid Cancer}

Levendag and co-workers [22] reported on 51 patients with anaplastic thyroid carcinoma. $45 \%$ had some kind of surgery, however, only 1 had radical surgery with microscopically free margins. $75 \%$ of the 28 patients without distant metastases at the beginning of radiotherapy treatment developed distant metastases within 6 months. The overall survival was poor. $94 \%$ died within the first year. Patients who received doses of less than $30 \mathrm{~Gy}$ had a median survival of only 0.6 months, which might be caused by the aggressive nature of the disease. In contrast, patients who received doses above $60 \mathrm{G}$ y had the best prognosis with 20\% 1-year survival and a median survival of 5.3 months. The main cause of death was residual tumor and local relapse. Complete response to radiotherapy at the end of treatment seems to correlate with the best prognosis ( 8 months median survival vs 1.6 months for none or incomplete responding tumors). Junor et al. [23] noted higher survival rates with increased radiation dose as well.

\section{Combined Therapeutic M odality}

$\mathrm{K}$ im and Leeper [24] reported on 19 patients with anaplastic giant and spindle cell carcinoma of the thyroid. 10 of them underwent subtotal thyroidectomy and modified neck dissection, 9 received only biopsy of the tumor. None of the patients showed any evidence of distant metastases at the time of treatment. A fter diagnosis, all of them received a combined therapeutic regimen consisting of administration of adriamycin ( $10 \mathrm{mg} / \mathrm{m}^{2}$, or a maximum of $20 \mathrm{mg}$ ), once weekly before hyperfractionated radiotherapy ( $1.6 \mathrm{G}$ y twice a day, 3 days/week, total dose $57.6 \mathrm{G}$ y in 40 days) was performed. I nitial complete tumor response rate was $84 \%$. L ocal tumor control rate 2 years after combined therapy was $68 \%$. The median survival time was 1 year, which is still significantly higher compared to the 5.3 months found by L evendag et al. [22] with high-dose irradiation alone. However, most patients promptly developed distant metastases and died from tumor-related causes. 0 ther authors found similar results with combined radiochemotherapy $[25,26]$.

\section{Conclusion}

Patients treated with combined extensive surgery, irradiation with total doses up to $60 \mathrm{~Gy}$, and chemotherapy, appear to have the best survival rates.

\section{References}

1 Leisner B, D egelmann G, Dir W, Kanitz W, B ühl U L anghammer $\mathrm{H}, \mathrm{L}$ issner J, Pabst $\mathrm{HW}$ : B ehandlungsergebnisse bei Struma maligna 1960-1980. D tsch M ed Wochenschr 1982:107:1702-1707.

2 A damietz IA, Schiemann MS, Petkauskas JG, Schemmann F, Böttcher HD: Prognostische Faktoren und Einfluß der Strahlentherapie bei Behandlung differenzierter Schilddrüsenkarzinome. Strahlenther Onkol 1998;174:618-623.
3 Saur HB, Lerch $H$, Schober 0 : Ü berlebenswahrscheinlichkeit von Patienten mit differenziertem Schilddrüsenkarzinom ohne primäre perkutane B estrahlung des $\mathrm{H}$ alsbereiches. Strahlenther O nkol 1996;172:306-311.

4 Sautter-Bihl ML, Herbold G, Heinze HG, Bihl H: Postoperative externe Radiotherapie des differenzierten Schilddrüsenkarzinoms: Wann ist eine alleinige Radiojodtherapie unzureichend? Strahlenther Onkol 1991;165:267-272.
5 G lanzmann $\mathrm{CH}$, Lütolf U M : L ong-term follow-up of 92 patients with locally advanced follicular or papillary thyroid cancer after combined treatment. Strahlenther O nkol 1992;168:260-269.

6 Sheline G E , G alante M , L indsay S: R adiation therapy in the control of persistent thyroid cancer. A $\mathrm{m} \mathrm{J}$ R oentgenol R ad Ther N ucl M ed 1966;97:923-930.

$7 O^{\prime}$ Connell ME, A'H ern RP, Harmer CL: Results of external beam radiotherapy in differentiated thyroid carcinoma: A retrospective study from the 
R oyal M arsden Hospital. E ur J Cancer 1994;30A : 733-739.

8Tubiana M, Haddad E, Schlumberger M, Hill C, Rougier $P$, Sarrazin D: External radiotherapy in thyroid cancers. Cancer 1985;55:2062-2071.

9T sang RW, B rierley JD, Simpson WJ, Panzarella T, Gospodarowicz MK, Sutcliffe SB: The effects of surgery, radioiodine and external radiation therapy on the clinical outcome of patients with differentiated thyroid cancer. Cancer 1998;82:375-388.

10 Phlips P, H anzen C, A ndry G, Van H outte P, Früuling I: Postoperative irradiation for thyroid cancer. E ur J Surg Oncol 1993;19:399-404

11 Samaan NA, Schultz PN, H ickey R C, G oepfert H, $\mathrm{H}$ aynie TP, Johnston DA, O rdonez NG : The results of various modalities of treatment of well differentiated thyroid carcinoma: A retrospective review of 1599 patients. J Clin Endocrinol Metab 1992;75: 714-720.

12 Lerch H, Schober O, Kuwert T, Saur H B: Survival of differentiated thyroid carcinoma studied in $500 \mathrm{pa}$ tients. J Clin O ncol 1997;15:2067-2075.

13 B enker G, O lbricht T, R einwein D, R einers C, Sauerwein $\mathrm{W}, \mathrm{K}$ rause $\mathrm{U}, \mathrm{M}$ lynek $\mathrm{ML}, \mathrm{H}$ irche $\mathrm{H}$ : Survival rates in patients with differentiated thyroid carcinoma. Influence of postoperative external radiotherapy. Cancer 1990;65:1517-1520.

14 Farahati J, R einers C, Stuschke M, M üller SP, Stüben G, Sauerwein W, Sack H: Differentiated thyroid cancer. I mpact of adjuvant external radiotherapy in patients with perithyroidal tumor infiltration (stage pT 4). Cancer 1996;77:172-180.

15 G eorgi P: Ü bereinstimmungen und Diskrepanzen bei der $\mathrm{R}$ adiojodtherapie des differenzierten Schilddrüsenkarzinoms. Nucl M ed 1992;31:45-50.

16 Tennvall J, B iörklund A , Torgil M , R anstam J, M ans $A$ : Is the E ORTC Prognostic index of thyroid cancer valid in differentiated carcinoma. Cancer 1986;57 1405-1414.

17 Chung CT, Sagerman R H, R yoo M C: External irradiation for malignant thyroid tumours. Radiology 1980;136:753-756.

$18 \mathrm{G}$ reenfield LD, George FW III: The role of radiotherapy in the management of medullary thyroid cancer. Int J R adiat O ncol Biol Phys 1979;5(suppl 1)

19 R ougier $P$, Parmentier $C, L$ aplanche $A$, L efevre $M$, Travagli JP, Caillou B, Schlumberger M, Lacour J, Tubiana M: Medullary thyroid carcinoma: Prognostic factors and treatment. Int J Radiat Oncol Biol Phys 1983;9:161-169.

20 Jensen H, D avis R K, D erreck L: Thyroid Cancer: A computer-assisted review of 5287 cases. O tolaryngol H ead N eck Surg 1990;102:51-65.

21 Fife $\mathrm{K} \mathrm{M}$, B ower $\mathrm{M}, \mathrm{H}$ armer C: M edullary thyroid cancer: The role of radiotherapy in local control. E ur J Surg Oncol 1996;19:399-404.

22 L evendag PC, D e Porre P, Van Putten W:A naplastic carcinoma of the thyroid gland treated by radiation therapy. Int J Radiat Oncol Biol Phys 1993;26: 125-128.

23 Junor EJ, Reed JP, Reed NS: A naplastic thyroid carcinoma: 91 patients treated by surgery and radiotherapy. E ur J Surg O ncol 1992:18:83-88.

$24 \mathrm{~K} \mathrm{im} \mathrm{J} \mathrm{H,} \mathrm{L} \mathrm{eeper} \mathrm{R} \mathrm{D} \mathrm{:} \mathrm{Treatment} \mathrm{of} \mathrm{locally} \mathrm{advanced}$ thyroid carcinoma with combination doxorubicin and radiation therapy. Cancer 1987:60:2372-2375.

25 Werner B, A bele J, A lveryd A , B jörklund A , Franzen $S$, G ranberg $P O, L$ andberg $T$, L undell $G$, L öwhagen $\mathrm{T}$, Sundblad R, Tennvall J: Multimodal therapy in anaplastic giant cell thyroid carcinoma. World J Surg 1984;8:64-70.

26 Schlumberger M , Parmentier C, D elisle M J, Couette JE, D roz JP, Sarrazin D: Combination therapy for anaplastic giant cell thyroid carcinoma. Cancer 1991;67:564-566.

\section{Gemeinsame J ahrestagung der \\ Deutschen und Österreichischen Gesellschaften für Hämatologie und Onkologie}

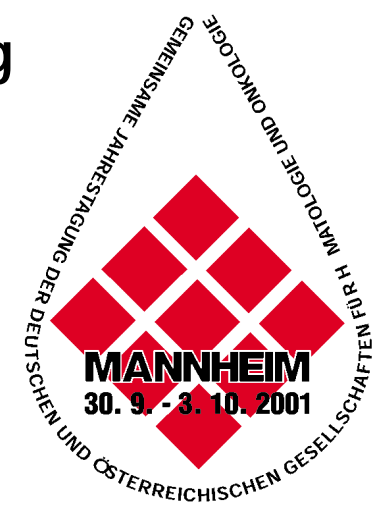

\subsection{9 bis 03.10 .2001 Mannheim \\ Congress Center Rosengarten}

$\begin{array}{ll}\text { Vorsymposien: } & \text { 29.- 30.9.2001 } \\ \text { Kongreß-Eröffnung: } & 30.9 .2001,16 \mathrm{Uhr}\end{array}$

\section{Thematische Schwerpunkte:}

- Biologie, Diagnostik und Therapie hämatologischer Systemerkrankungen und maligner Tumoren

- Multimodale Therapieansätze in der Onkologie

- Zelluläre Immuntherapie

- Klinische Pharmakologie antineoplastischer Substanzen

- Spättoxizität der Strahlen- und Chemotherapie

- Pflege- und Palliativkongreß

- Young Masters Turnier

u. a.

\section{Einsendeschluß für freie Beiträge: 31. Mai 2001 www.dgho.2001-mannheim.de}

Kongreßpräsident: Ko-Präsident:

Kongreßsekretäre:

Organisation:
Prof. Dr. Rüdiger Hehlmann Prof. Dr. Wolfgang Queißer

Dr. Ute Berger

PD Dr. Andreas Hochhaus

III. Medizinische Universitätsklinik

Klinikum Mannheim der Univ. Heidelberg Wiesbadener Straße 7-11 68305 Mannheim dgho.2001@urz.uni-heidelberg.de

Tel. +4962138341 15/-4176

Fax +496213834239

meet ideas

Congressgestaltung und Organisation Ausstellungsorganisation

Sven Vierhuff

dgho.2001@meet-ideas.de

Tel. +49621 4106-152

Fax +49621 4106-202 